\title{
ANALISIS SOSIAL TERHADAP SEKOLAH UNGGULAN DAN NON UNGGULAN KABUPATEN ENREKANG
}

\author{
Sri Iril Anjani ${ }^{1}$, Nursalam $^{2}$, Risfaisal $^{3}$ \\ ${ }^{1}$ Pendidikan Sosiologi, Universitas Muhammadiyah Makassar \\ Email: anjani@gmail.com \\ ${ }^{2}$ Pendidikan Sosiologi, Universitas Muhammadiyah Makassar \\ Email: nursalam@unismuh.ac.id \\ ${ }^{3}$ Pendidikan Sosiologi, Universitas Muhammadiyah Makassar \\ Email: risfaisal@unismuh.ac.id
}

\begin{abstract}
Abstrack. The general objective of this study is to find out the social point of view about the difference in quality between superior and non-excellent schools, To find out people's perceptions of disadvantages, and strengths between featured and non-featured schools. Specifically, this research was conducted with the aim of knowing and describing the Knowing specifically which became a discourse on social differences about superior and non-excellent schools. As for the type of research that will be used in this study is the type of qualitative research and the approach in this research is the phenomenological approach.

The data analysis in this study are as follows: Data Collection, Data Reduction, Data Presentation, Conclusion Withdrawal and verification, and other than that the Research Instrument is carried out. the following researchers interview or interview and observation

The results of the analysis of the results of interviews with the community relate to the point of view of superior and non-excellent schools where the community sees the quality of schools in terms of decent facilities and it is only owned by superior schools where facilities in terms of education are almost all include in excellent schools while non-excellent schools do not have less than the maximum, the next quality produced by excellent schools is better than non-excellent schools where

the system of how to educate in primary schools $\mathrm{n}$ is better than in non-leading schools. In accordance with the results of the study in which the opinion of the government that only implements the rules has been treated, the government is not willing to take a decision where the government only follows something that has been determined in the procurement of superior and non-excellent schools in where they only run in accordance with the jobs they have lived in and followed the rules and if the school meets the rules the government has no right to postpone it.
\end{abstract}

Keywords: Social Analysis, Featured and Non-Featured Schools

Tujuan umum dari penelitian ini adalah Untuk mengetahui sudut pandang sosial tentang perbedaan kualitas antara sekolah unggulan dan non unggulan, Untuk mengetahui persepsi masyarakat dari segi kekurangan, dan kelebihan antar sekolah unggulan dan non unggulan. Secara khusus penelitian ini dilakukan dengan tujuan untuk mengetahui dan mendeskripsikan tentang Mengetahui secara khusus yang menjadi wacana perbedaan di sosial tentang sekolah unggulan dan non unggulan Faktor-faktor yang membedakan antar sekolah unngulan dan non unggulan. Adapun Jenis penelitian yang akan digunakan pada penelitian ini adalah Jenis penelitian kualitatif dan Pendekatan dalam penelitian ini yaitu pendekatan fenomenologi.

Adapun Analisis data dalam penelitian ini adalah sebagai berikut : Pengumpulan Data, Reduksi Data, Penyajian Data, Penarikan Kesimpulan dan verifikasi dan selain itu adapun Instrumen Penelitian di lakukan peneliti sebgaia berikut Interview atau wawancara dan Observasi. 
Hasil analisis dari hasil wawancara dengan masyarakat berkaitan dengan sudut pandang terhadap sekolah unggulan dan non unggulan di mana masyarakat melihat kualitas sekolah dari segi fasilitas yang layak dan itu hanya dimiliki oleh sekolah unggulan di mana fasilitas dalam hal dunia pendidikan hampir semua mencakupi di sekolah unggulan sedangkan sekolah non unggulan bukannya tidak memiliki Cuma kurang maksimal, Yang selanjutnya kualitas yang di hasilkan oleh sekolah unggulan lebih baik dibandingkan sekolah non unggulan di mana sistem cara mendidik di sekolah unggulan lebih baik dibandingkan di sekolah non unggulan,

Sesuai hasil penelitia di mana pendapat dari pihak pemerintah yang hanya menjalankan aturan sudah di perlakukan, pemerintah tidak aslal ambil keputusan di mana parapemerintah hanya mengikuti seusatu yang sudah di tetapkan dalam hal pengadaan sekolah unggulan dan non unggulan dimana mereka hanya menjalankan sesuai dengan job yang telah mereka tempati dan ikuti aturan dan apabila sekolah sudah memenuhi aturan maka pemerintah tidak berhak menundanya.

Kata Kunci : Analisis Sosial, Sekolah Unggulan dan Non Unggulan

\section{PENDAHULUAN}

Manusia merupakan makhluk individu sekaligus makhluk sosial. Sebagai makhluk individu setiap manusia memiliki cirri khas,keinginan,kepribadian,dan watak yang berbeda-beda. Dilain sisi manusia juga merupakan makhluk sosial yang membutuhkan manusia lain dalam menjalani hidupnya. Dalam hubungannya sebagai makhluk sosial, manusia selalu hidup bersama orang lain atau berkelompok. Ketika manusia hidup bersama dengan orang lain maka hubungan sosial atau interaksi sosial menjadi kebutuhan dasar bagi manusia.

Pendidikan merupakan salah satu hal yang penting dalam kehidupan seseorang. Melalui pendidikan seseorang dapat meningkatkan kecerdasan, keterampilan, mengembangkan potensi diri, dan dapat membentuk kepribadian yang bertanggung jawab, cerdas, dan kreatif . Dengan adanya pendidikan sosial manusia dapat terbina dan dapat terwujud dengan baik dan dapat pula mensejahterakan kehidupan manusia. Secara Sederhana Pendidikan dapat di artikan sebagai usaha manusia untuk membina kepribadiannya sesuai dengan nilai-nilai yang ada di dalam masyarakat dan kebudayaan. Dalam perkembangannya, istilah pendidikan atau pedagogik yang berarti membimbing atau pertolongan yang diberikan dengan sengaja dilakukan oleh orang dewasa atau tenaga pedidik agar anak didiknya menjadi dewasa. Pendidikan diartikan pula sebagai usaha yang dijalankan orang lain agar menjadi dewasa atau mencapai hidup atau penghidupan lebih tinggi dalam arti mental.

Untuk mencapai tujuan pendidikan maka diperlukan seorang guru yang profesional baik dalam penyampaian materi, penggunaan metode, pengelolaan kelas, dan sebagainya. Selain itu diharapkan kepada guru untuk lebih kreatif melakukan kegiatan pendukung pembelajaran di dalam kelas dengan membina siswa untuk mengembangkan bakat yang dimilikinya. Dalam hal ini guru sebaiknya menyiapkan wadah untuk siswa agar dapat mengembangkan potensi dalam diri siswa sehingga bakat yang dimiliki siswa dapat tersalurkan dengan baik. Karena Tidak bisa dipungkiri bahwa guru sebagai penopang dan pembangsa dan mampu menciptakan peradaban dunia yang lebih baik.

Untuk belajar dengan baik maka diperlukan motivasi yang baik pula. Siswa yang mengikuti pelajaran tanpa adanya motivasi maka tidak akan mendapatkan hasil yang baik dari proses belajar mengajar tersebut. Oleh karena itu, dapat dikatakan bahwa motivasi merupakan daya penggerak di dalam diri siswa untuk dapat belajar, yang dapat menjamin kelangsungan dari proses belajar mengajar dan memberikan arah pada kegiatan belajar, sehingga tujuan yang akan dicapai dalam proses belajar dapat terwujud. Penggunaan media dalam proses belajar merupakan salah satu cara yang dapat digunakan untuk membangkitkan motivasi belajar siswa. Karena media, merupakan salah satu hal mutlak yang ada dalam proses belajar. Oleh karena itu, sebisa mungkin guru harus bisa menggunakan media pembelajaran dalam proses belajar.

Media yang menarik akan mempengaruhi motivasi belajar, ketika siswa menilai bahwa apa yang ditampilkan oleh guru itu menarik maka ia akan terdorong atau merasa tertantang untuk 
mengetahui apa yang akan di sampaikan oleh guru sehingga proses belajar akan menjadi lebih menyenangkan. Tetapi sebaliknya jika siswa menilai apa yang ditampilkan guru tidak menarik maka siswa akan datar saja dalam mengikuti proses. Setiap orang berhak untuk mendapatkan pendidikan. Pada dasarnya pendidikan itu mengajarkan setiap individu untuk berpikir dan bertindak mencerminkan dirinya sebagai individu penerus generasi yang baik. Pendidikan dewasa ini sudah banyak melahirkan berbagai macam model pendidikan. Pendidikan formal ataupun non formal, contohnya mulai dari pendidikan anak usia dini, pendidikan homeschooling, pendidikan khusus bagi para masyarakat yang kurang mampu dan pendidikan umum negeri maupun swasta mulai dari Taman Kanak-kanak hingga ke Perguruan Tinggi, yang bertaraf Nasional dan Internasional.

Pendidikan dapat diartikan sebagai bimbingan secara sadar oleh pendidik terhadap perkembangan jasmani dan rohani peserta didik menuju terbentuknya kepribadian yang utama. Sehingga pendidikan dipandang sebagai salah satu aspek yang memiliki peranan pokok dalam membentuk generasi muda agar memiliki kepribadian yang utama.(Zuhairini, 1993: 9)

Dalam undang-undang nomor 20 tahun 2003 tentang system pendidikan nasional dijelaskan bahwa jalur pendidikan itu terbagi menjadi tiga yaitu : pendidikan formal, pendidikan non formal, dan pendidikan informal, sehingga menimbulkan tiga lembaga pendidikan pula.

Pendidikan Non formal adalah jalur pendidikan diluar pendidikan formal yang dapat dilaksanakan secara terstruktur dan berjenjang. Menurut Undang- Undang Sistem Pendidikan Nasional, Pendidikan non formal diselenggarakan bagi warga masyarakat yang memerlukan layanan pendidikan yang berfungsi sebagai pengganti, penambah, dan pelengkap pendidikan formal dalam rangka mendukung pendidikan sepanjang hayat. Serta berfungsi untuk mengembangkan potensi peserta didik dengan penekanan pada penguasaan pengetahuan dan keterampilan fungsional serta pengembangan sikap dan kepribadian profesional.

Pendidikan formal adalah pendidikan yang berstruktur hierarkis dan memiliki kelas yang berurutan dari Sekolah Dasar sampai Universitas yang termasuk juga di dalamnya kegiatan tambahan bagi studi akademik umum dengan bermacam-macam program juga lembaga khusus untuk pelatihan teknis dan profesional. (Mustofa Kamil, 2009:10)

Sekolah unggulan adalah sekolah yang mampu membawa setiap siswa mencapai kemampuan secara terukur dan mampu di tunjukan perstasinya tersebut, Tipe ini yaitu, dimana sekolah menerima dan menyeleksi secara ketat siswa yang masuk dengan kriteria memiliki prestasi akademik yang tinggi. Sedangkan sekolah Non unggulan yaitu sekolah yang kurang mampu membawa setiap siswa mencapai kemampuannya secara terukur dan kurang dalam penunjukan prestasi , dikarenakan berbagai hal. Misalnya, kurangnya fasilitas sekolah, kurangnya kinerja guru dalam hal ini penggunaan metode dan media pembelajaran dan bisa saja dilabelkan sekolah yang kurang memiliki cerita baik di kalangan masyarakat baik dari segi mutu dan kualitas sekolah.

Peranan sekolah sebagai lembaga pendidikan adalah mengembangkan potensi manusiawi yang dimiliki anak-anak agar mampu menjalankan tugas- tugas kehidupan sebagai manusia, baik secara individual maupun sebagai anggota masyarakat. Kegiatan untuk mengembangkan potensi itu harus dilakukan secara berencana, terarah dan sistematik guna mencapai tujuan tertentu. Tujuan itu harus mengandung nilai-nilai yang serasi dengan kebudayaan pendidikan. Oleh karena itulah, maka dapat dikatakan bahwa fungsi sekolah adalah meneruskan, mempertahankan dan mengembangkan kebudayaan suatu masyarakat, melalui kegiatan ikut membentuk kepribadian anak-anak agar menjadi manusia dewasa yang mampu berdiri sendiri didalam kebudayaan dan masyarakat sekitarnya. Dengan kata lain sekolah berfungsi mempersiapkan pengganti generasi yang kelak mampu mempertahankan eksistensi kelompok atau masyarakat. Sekolah unggulan adalah sekolah yang mampu membawa setiap siswa mencapai kemampuan secara terukur dan mampu di tunjukan perstasinya tersebut, dan yang ingin dibahas disini sekolah unggulan dan non unggulan yang ada di kabupaten Enrekang dimana diketahui daerah Enrekang daerah yang bisa dikata jauh dari jangkauan ibu kota provinsi bisa di kategorikan Enrekang adalah daerah yang pedalaman di mana sudut pandang masyarakat saat ini bahwa sekolah unggulan bisa bersaing dengan sekolah manapun, hal ini 
masih menjadi tanda Tanya bagi kita karena dari sudut pandang beberapa orang pernah meneliti daerah pedalaman mengatakan bahwa "daerah yang tidak dijangkau oleh teknologi tidak bisa di kategorikan daerah yang unggulan" sedangkan diketahui bahwa Enrekang adalah daerah bisa dikata pedalaman dan susah dijangkau teknologi karena kondisi wilayahnya, tapi lagi lagi di sini di bahas sudut pandang masyarakat tentang sekolah unggulan dan non unggulan.

Fakta-fakta yang masuk di sekolah unggulan ada beberapa syarat yang harus dipenuhi di antaranya nilai kedisiplinan di sekolah SMP sebelumnya, prestasi yang didapat, dan nilai keseharian juga lingkungan harus memenuhi standar yang telah di tetapkan oleh pemerintah sebagai syarat sekolah unggulan, sedangkan sekolah non unggulan adalah sekolah yang tidak menuntu terlalu banyak syarat agar dapat mempermudah bagi anak-anak yang tidak memiliki prestasi dapat bersekolah, dan kebanyakan sekolah non unggulan ini bisa di kata berstatus swasta, di mana faktanya yang di kenal oleh masyarakat adalah siswanya bisa bebas keluar masuk sekolah, tata tertib tidak terlalu tegas terhadap siswa.

Sekolah di Enrekang adalah sekolah yang bisa dikata lebih mengutamakan pembelajaran tentang ajaran agama karena di kabupaten Enrekang lebih dominan satu agama yaitu agama islam dan hampir semua sekolah memiliki jam pembelajaran khusus tentang agama, karena pemahaman tentang pembelajaran agama adalah dapat memperbaiki ahlak para siswa di lingkungan, dan ini salah satu bukti yang di miliki kebanyakan siswa seperti mereka tidak pernah tauran dengan sekolah sekolah yang lain bahkan mereka lebih berusaha untuk memperkuat ikatan petemanan dengan sekolah lain dan paradigma ini hampir dimiliki semua sekolah di Enrekang entah sekolah unggulan ataupun sekolah non unngulan.

Adapun yang melatarbelakangi sehingga peneliti mengangkat judul penelitian ini adalah karena di kabupaten Enrekang masih banyak perbedaan-perbedaan tentang lingkungan sekolah terkhusus bagi sekolah unggulan dan non unggulan yang ada di kabupaten Enrekang, Mengingat pentingnya nama baik di lingkungan sosial terkhusus bagi sekolah unggulan terhadap sudut pandang masyarakat di mana sudut pandang masyarakat yang melihat keunggulan dari beberapa sisi berbeda dengan sudut pandang peneliti yang pernah meneliti langsung lingkungan sosial, Sesuai dengan pembahasn di atas maka peneliti mengangkat judul "Analisis Sosial Terhadap Sekolah Unggulan dan Non Unggulan Kabupaten Enrekang"

\section{Tinjauan pustaka}

\section{Teori Konstruksi Sosial}

Herbert Mead Melihat Teori konstruksi sosial sebagai realitas dalam sistem sosial diciptakan melalui interaksi timbal balik yang menghasilkan sistem nilai dan keyakinan. Sistem nilai dan keyakinan tersebut dipraktikkan dan diperankan berulang-ulang oleh aktor sosial sehingga melekat dalam sistem yang kemudian dianggap sebagai realitas. Realitas tersebut masuk kedalam individuindividu melalui proses internalisasi, dipraktikkan berulang melalui proses yang disebut eksternalisasi hingga melekat dalam institusi sistem sosial.

\section{Teori Tindakan Sosial}

Weber melihat sosiologi sebagai sebuah studi tentang tindakan sosial antar hubungan sosial dan itulah yang dimaksudkan dengan pengertian paradigma definisi sosial dan itulah yang di maksudkan dengan pengertian paradigma definisi atau ilmu sosial itu. Tindakan manusia dianggap sebagai sebuah bentuk tindakan sosial yang manakala tindakan itu ditujukan pada orang lain.

Sekolah unggulan dan non uggulan di kabupaten Enrekang di ambil dari beberapa sudut pandang sosial di mana terdapat perbedaan yang dapat dilihat dengan mata telanjang oleh sosial mulai dari lingkungan, kondisi sekolah, keadaan murid dll. dan teori tentang sekolah unggulan di mata masyarakat adalah di mana sekolah di utamakan di bandingkan sekolah non unggulan selama ini yang di anggap sekolah pembuangan bagi masyarakat dan paradigma ini sudah tidak bisa lagi di pungkiri, karena pada dasarnya sifat dasar manusia apa yang dilihat itu dipercaya, sesuai dengan 
teori tindakan sosial yang di kemukakan oleh max weber membahas tentang paradigma sosial.

\section{Teori Konstruksi Sosial}

Herbert Mead Melihat Teori konstruksi sosial sebagai realitas dalam sistem sosial diciptakan melalui interaksi timbal balik yang menghasilkan sistem nilai dan keyakinan. Sistem nilai dan keyakinan tersebut dipraktikkan dan diperankan berulang-ulang oleh aktor sosial sehingga melekat dalam sistem yang kemudian dianggap sebagai realitas. Realitas tersebut masuk kedalam individuindividu melalui proses internalisasi, dipraktikkan berulang melalui proses yang disebut eksternalisasi hingga melekat dalam institusi sistem sosial.

\section{Teori Tindakan Sosial}

Weber melihat sosiologi sebagai sebuah studi tentang tindakan sosial antar hubungan sosial dan itulah yang dimaksudkan dengan pengertian paradigma definisi sosial dan itulah yang di maksudkan dengan pengertian paradigma definisi atau ilmu sosial itu. Tindakan manusia dianggap sebagai sebuah bentuk tindakan sosial yang manakala tindakan itu ditujukan pada orang lain.

Sekolah unggulan dan non uggulan di kabupaten Enrekang di ambil dari beberapa sudut pandang sosial di mana terdapat perbedaan yang dapat dilihat dengan mata telanjang oleh sosial mulai dari lingkungan, kondisi sekolah, keadaan murid dll. dan teori tentang sekolah unggulan di mata masyarakat adalah di mana sekolah di utamakan di bandingkan sekolah non unggulan selama ini yang di anggap sekolah pembuangan bagi masyarakat dan paradigma ini sudah tidak bisa lagi di pungkiri, karena pada dasarnya sifat dasar manusia apa yang dilihat itu dipercaya, sesuai dengan teori tindakan sosial yang di kemukakan oleh max weber membahas tentang paradigma sosial.

\section{METODE PENELITIAN}

Jenis penelitian yang akan digunakan pada penelitian ini adalah Jenis penelitian kualitatif. Jenis Penelitian Kualitatif artinya data terurai dalam bentuk kata-kata atau gambar-gambar, bukan dalam bentuk angka-angka. Pendekatan kualitatif yang bersifat deskriptif ini berpandangan bahwa semua hal yang berupa sistem dan tidak ada yang patut diremehkan, semuanya penting, dan semuanya mempunyai pengaruh dan kaitan dengan yang lain.

Pendekatan dalam penelitian ini yaitu pendekatan fenomenologi dimana salah satu jenis penelitian kualitatif yang di aplikasikan dalam fenomena yang terjadi langsung di lapangan, untuk mengungkap dengan jenis penelitian yang di jelaskan paragraf petama yaitu penelitian kualitatif di mana sang peneliti akan terjun langsung di lingkungan sosial untuk mendapatkan data-data yang di butuhkan seperti dokumentasi, wawancara dan peneliti juga akan terjun langsung kelapangan di mana tempat lingkungan di sekitar sekolah untuk mendapatkan data langsung dari masyarakat.

Informan dalam penelitian adalah orang atau pelaku yang benar-benar tahu dan menguasai masalah, serta terlibat langsung dengan masalah penelitian. Dengan menggunakan metode penelitian kualitatif, maka peneliti sangat erat kaitannya dengan faktor-faktor kontekstual, jadi dalam hal ini sampling dijaring sebanyak mungkin informasi dari berbagai sumber. Maksud kedua dari informan adalah untuk menggali informasi yang menjadi dasar dan rancangan teori yang dibangun.

Pemilihan informan sebagai sumber data dalam penelitian ini adalah berdasarkan pada asas subyek yang menguasai permasalahan, memiliki data, dan bersedia memberikan informasi lengkap dan akurat. Informan yang bertindak sebagai sumber data dan informasi harus memenuhi syarat, yang akan menjadi informan nara sumber (keyinforman) dalam penelitian ini adalah masyarakat sekitar sekolah dan guru-guru sekolah tempat penelitian . 
Penelitian kualitatif tidak dipersoalkan jumlah informan, tetapi bisa tergantung dari tepat tidaknya pemilihan informan kunci, dan komplesitas dari keragaman fenomena sosial yang diteliti. Dengan demikian, informan ditentukan dengan teknik snowball sampling, yakni proses penentuan informan berdasarkan informan sebelumnya tanpa menentukan jumlahnya secara pasti dengan menggali informasi terkait topik penelitian yang diperlukan. Pencarian informan akan dihentikan setelah informasi penelitian dianggap sudah memadai.

\section{HASIL DAN PEMBAHASAN}

\section{Persepsi Masyarakat Terkait Dengan Sekolah Unggulan Dan Non Unggulan}

Persepsi masyarakat tentang sekolah unggulan dan non unggulan itu sudah bukan rahasia lagi di mana orang tua akan berusaha memasukan anaknya ke sekolah unggulan tanpa berfikir panjang, kalau di fikir secara logis khususnya SMA sederajat itu bukan lagi persoalan tentang unggulnya atau tidak, tergantung dari individu masing-masing karena kebanyakan selama ini yang dinilai dari sebuah sekolah bukan dari seberapa banyak siswa yang dia terima, dan terkadang sekolah unggulan menurun menjadi non unggulan dan begitupun sebaliknya dalam artian bahwa penilaian selama ini diambil dari kualitas siswa dan guru, sekolah bukanlah sesuatu yang cerdas atau benda mati yang sedang berkembang tetapi sekolah adalah wadah kosong yang di isi oleh orang-orang dengan tujuan tertentu atau sekolah merupakan wadah kosong yang ingin dikembangkan oleh orang-orang dengan tujuan untuk berproses dan menghasilkan sebuah input di mana input itu akan di kenal oleh masyarakat bukan siswanya yang akan dikenal pertama tetapi sekolahnya.

Dari latar belakang di atas bahwa sekolah unggulan dan non unggulan itu tergantung dari orang- orang yang berada di dalamnya dengan output yang bisa di akui, dalam artian bahwa semua sekolah berusaha untuk menjadi lebih baik, dan seharusnya sekolah unggulan dan non unggulan itu tidak di beda-bedakan seperti hasil wawancara yang dilakukan dengan beberapa pihak sekolah tentang sekolah unggulan dan non unggulan :

Saya sebenarnya tidak terlalu sepakat terhadap kelas unggulan dikarenakan sepemahaman saya seakan-akan di diskriminasi apabila dikotak-kotakkan antara unggulan dan non-unggulan, bahkan menurut saya sebaiknya diratakan semua karena pada dasarnya semua orang sama serta berhak mendapatkan perlakuan dan pendidikan yang sama. Kebetulan saya Alumni Psikologi dan dalam Psikologi tidak ada kelas Unggulan. (Hasil Wawancara/FA/29/7/2019)

Hasil pemaparan dari informan yang berinisial FA mempersepsikan melalui sudut pandang yang mengatakan bahwa sekolah itu sama semua fungsinya di mana tempat menempuh ilmu bukan sesuatu yang di tempati bersaing siapa yang lebih unggul akan tetapi tujuan penerapan untuk sekolah unggulan dan non unggulan adalah sebuah pengharagaan yang telah di capai dalam sebuah sekolah bukan dari segi persaingan yang di lakukan tapi ini dari segi sesuatu yang dapat membuat para murid menjadi lebih bermotivasi dalam menuntut ilmu misalnya kalau seorang siswa bisa mencapai target yang telah di janjikan atau standar dari sebuah istansi maka dia bisa mendapatkan beasiswa dan ini tidak terkhusus kepada sekolah unggulan

terkumpulnya siswa yang berprestasi serta proses bimbingannya sudah bagus, hanya saja dalam perspektif masyarakat melahirkan dikotomi,disintegrasi, seolah-olah siswa yang diterima disekolah tersebut hanya siswa yang memiliki kemampuan akademik bagus serta ekonomi materi .(hasil wawancara/SI/30/7/2019)

Setiap pandangan masyarakat memiliki perbedaan seperti persepsi salah satu masyarakat yang berinisial SI dimana dia melihat dari sisi positif pengadaan sekolah unggulan dan non unggulan dengan memanfaatkan prestasi yang bakalan muncul karena tidak bisa di pungkiri karakter setiap siswa itu berbeda beda dan tidak semua bidang bisa di andalkan setiap siswa pasti ada kemampuan 
yang paling menonjol di suatu bidang, setiap pengadaan perlombaan dengan berbagai jenis perlombaan tidak semua siswa bisa melakukanya dan tidak semua siswa bisa menguasai semua bidang tersebut, sebenarnya tidak ada siswa yang bodoh Cuma, kemampuan setiap siswa berbeda beda, dan masih banyak siswa membutuhkan bimbingan para guru untuk memahami bidang dan meningkatkan kemampuan mereka.

Sekolah unggulan yaitu sekolah yang dimana mempunyai kualitas yang bagus dalam segi fasilitas, dengan fasilitas mapan tentunya proses belajar mengajar yang efektif, kalau non unggulan tentunya fasilitasnya itu tidak memadai sehingga proses belajar mengajar tidak akan berjalan dengan baik. .

(hasil wawancara /RH/31/7/2019)

Salah satu persepsi masyarakat yang bisa dikata memiliki pandangan yang benar benar tarjadi di ingkungan bahkan bukan Cuma sekolah, kampus pun begitu di mana dia melihat sekolah unggulan pada saat penerimaan bisa dikatakan lumayan ketat walaupun hampir semuanya tidak begitu tapi sekolah unggulan melakukan tahap demi tahap dalam seleksi penerimaan siswa baru, tapi ini menunjukan bahwa setiap sekolah ingin memaksimalkan kualitas walaupun belum semaksimal yang di harapkan,

Terkait dengan hasil wawancara yang dilakukan peneliti sala satu pendapat dari informan yang melihat dari sudut pandang positif dari berbagai segi yang dapat dia perhatikan memang hampir semua sekolah unggulan lebih unggul dari segi fasilitas tapi pendapat dari hasil wawancara dikatakana dari sala satu informan yang melihat juga melihat sebuah keunggulan dari segi bakat

Apabila berbicara dari segi kualitas memang lebih berkualitas di sekolah unggulan namun kenyataannya dalam dunia pendidikan bukan hanya prestasi yang dikejar melainkan ada juga pengembangan bakat yang dikejar dan orientasinya sekarang bukan hanya pengetahuan yang dimunculkan tetapi bakat juga dimunculkan. .(hasil wawancara/HS/31/7/2019)

Sesuai hasil wawancara di atas sala satu sumber informan yang berinisial RH melihat dari sudut pandang hubungan kerjasama dengan pendidikan lainnya di mana sekolah unggulan memiliki kerjasama dengan pendidikan yang lebih tinggi dan kapasitas untuk murid yang di janjikan lebih besar di bandingkan sekolah nonunggulan.

Bicara tentang kualitas sekolah unggulan dan sekolah non unggulan, maka kita akan mengkaitkannya dengan beberapa faktor penunjang kualitas sekolah baik dari segi fasilitas sarana dan prasarana serta tenaga didik pada sekolah tersebut, yang mana kita ketahui bahwa kedua klasifikasi sekolah tersebut memiliki faktor penunjang akan tetapi faktor penunjang pada sekolah unggulan jauh lebih maksimal dibandingkan dengan sekolah non unggulan. .( hasil wawancara/MY/4/8/2019)

Berkaitan dengan hasil wawancara dengan sala satu sumber informan yang berinisial MY di mana dia melihat kualitas sebuah sekolah dari segi dari segi faktor penunjang di mana faktor penunjang yang di maksud adalah sebuah kapasitas yang di miliki sebuah sekolah untuk meningkatkan pengetahuan para siswa

Berkaitan dengan hasil wawancara dengan sumber informan yang berinisial FR berkaitan dengan standar sekolah dengan melihat standar untuk jadi sekolah unggulan di mana dia melihat segi akreditas dan tenaga pendidik,di mana sumber informan mengaggap sekolah yang baik adalah sekolah yang memiliki akreditasi yang bagus dan guru-guru yang berkompeten. 
Syaratnya yaitu dari segi fasilitas yang mana terdapat laboratorium yang lengkap, perpustakaan yang lengkap serta klasifikasi guru yang berkompeten minimal S1.

(hasil wawancara /LZ/4/8/2019)

Sarana media pembelajaran yang paling utama adalah sebuah wadah untuk berkumpul dan sala satu hasil wawancara di mana sumber informan yang berinisial LZ melihat dari segi prasarana gedung sebagai media pembelajaran, memang tidak bisa di pungkiri bahwa gedung untuk para siswa sangatlah wajib dalam menimpah ilmu dan beberapa fasilitas pendukung yang melengkapi gedung tersebut, apalagi sekarang sekolah sudah semakain berkembang berbagai macam gedung telah di bangun mulai laboratorium yang bermacam macam agar para siswa dapat fokus dalam pembelajar di bidang tersebut

Untuk strateginya pasti berbeda dikarenakan beda kepala beda watak dan karakter jadi untuk perlakuan ke siswanya masing-masing juga berbeda, serta seharusnya guru itu pintar dan berinovatif. (hasil wawancara/FR/4/8/2019)

Berkaitan dengan hasil wawancara dengan sala satu sumber informan yang berinisial FR tentang strategi, setiap tenaga pengajar memiliki cara yang berbeda beda sesuai dengan kemampuan dan sesuatu yang mereka anggap sesuai dengan bahan ajar yang mereka bawakan, tetapi kadang ada juga beberapa guru yang memahami konsep para siswa atau kondisi para siswa di mana para siswa tidak bisa menangkap apa yang akan di bawakan oleh guru tersebut dan ini sering terjadi oleh para siswa dan berkaitan dengan hasil wawancara sebelumnya di mana kemampuan daya tanggap siswa itu berbeda beda di sini para guru juga harus kreatif dalam membawakan materi kepada siswa dan memahami kondisi siswa agar siswa dapat menerima pembelajarn tersebut tanpa beban. di mata masyarakat.

Hasil analisis dari hasil penelitian di mana Masyarakat lebih melihat dari segi kualitas dan sarana dan prasarana sekolah di mana sesuatu yang bisa di lihat dengan kasat mata oleh masyarakat maka akan memunculkan paradigma masyarakat terhadap sekolah unggulan lebih baik dari pada sekolah non unggulan secara otomatis akan mempengaruhi dampak Sistem sekolah non unggulan kurang maksimal dibandingkan sekolah unggulan dalam persoalan sitem dimata masyarakat dan para Orang tua murid lebih mengutamakan sekolah unggulan untuk menyekolakan anaknya karena memiliki fasilitas dan sarana prasarana yang lengkap seperti di pembahasan hasil penelitian dimana sekolah unggulan memiliki nilai positif yang lebih di mata masyarakat di bandingkan sekolah non unggulan tapi strategi sebuah sekolah tidak berkurang untuk memperbaiki sekolah semaksimal mungkin karena itu bisa di kata kewajiban setiap guru yang bertanggung jawab di sekolah walaupun pandangan masyarakat Strategi setiap sekolah berbeda dan strategi sekolah unggulan lebih baik dibandingkan sekolah non unggulan.

\section{Kebijakan Pemerintah Terhadap Implementasi Aturan Di Sekolah Unggulan dan Non Unggulan}

Sekolah unggulan adalah sekolah dengan keunggulan pada semua komponen atau aspek, ada pandangan masyarakat pendidikan dan masyarakat umum bahwa sekolah dapat dikatakan unggulan bilamana mampu menghasilkan lulusan dengan nilai UN atau transkip nilai yang tinggi melalui proses pembelajaran yang baik. Dalam perspektif teoritik keunggulan tersebut dinamakan dengan keunggulan mutio dimensional.

Adapun pendapat salah satu dari pemerintah di bagian bidang Seksi kurikulum dan pembelajaran megatakan :

Persoalan kebijakan dari pemerintah terkhusus dari saya, saya hanya bisa konsisten terhadap aturan yang telah di perlakukan di beberapa aturan yang telah di kaji oleh pemerintah dengan berbabagai macam pertimbnagan dan bagi saya dan teman saat hanya bisa ikuti aturan yang telah tertulis, seperti halnya pengadaan 
sekolah unggulan dan non unggulan kami tidak bisa menetapkan begitu saja, sudah ada aturan yang harus di ikuti dan apa bila sekolah tersebut sudah memenuhi standar menjadi sekolah unggulan maka kami tinggal menertapkan dalam artian bukan kami yang yang membuat sekolah menjadi baik tapi mereka sendiirilah yang membuat sekolah menjadi baik.

(hasil wawancara /DP/2/8/2019)

Di mana salah satu pendapat sumber informan yang berinisial DP dari pihak pemerintah bidang Seksi kurikulum dan pembelajaran mengatakan tentang persoalan kebijakan dari pemerintah yang telah tertulis dan di jalankan oleh para pemerintah dalam artia bahwa pemerintah tidak bisa ambil keputusan secara mendadak harus ada perizinan dan kesesiauan dari aturan yang telah tertulis, yakni :

Kebijakan dari pemeritah terhdap sekolah unggulan dan non unggulan bagi saya itu sudah ditetapkan, ada aturan di atas kertas kami tidak bisa megeluarkan kebikajakan begitu saja, dalam hal kebijakan kami harus memahami aturan yang telah di perlakukan seperti penyelenggaraan sekolah unggulan dan non unggulan, itu sudah memang ada aturanya, ya tinggal sekolah saja yang memenuhi standar untuk menjadi sekolah unggulan dan apabila mereka sudah memenuhinya maka kami tidak punya hak untuk menundanya(hasil wawancara/HS/2/8/2019/)

Berkaitan dengan hasil wawancara bisa di kata pendapat dari sumber informan beranisial HS bidang Seksi Pendidikan Masyarakat Kursus dan Pembelajaran hanya memiliki perbedaan redaksi kata di mana sama sama menjelaskan tentang cara kebijakan para pemerintah untuk pengadaan sekolah unggulan dan non unggulan.

Sesuai hasil penelitian di mana pendapat dari pihak pemerintah yang hanya menjalankan aturan sudah di perlakukan, pemerintah tidak asal ambil keputusan di mana parapemerintah hanya mengikuti seusatu yang sudah di tetapkan dalam hal pengadaan sekolah unggulan dan non unggulan di mana mereka hanya menjalankan sesuai dengan job yang telah mereka tempati dan ikuti aturan dan apabila sekolah sudah memenuhi aturan maka pemerintah tidak berhak menundanya.

\section{KESIMPULAN}

Berdasarkan hasil penelitian dan pembahasan. serta temuan peneliti di lapangan yang telah dilakukan peneliti dapat menarik kesimpulan sebagai pernyataan singkat yang diharapkan dapat memberikan jawaban atas masalah yang diangkat dalam penelitian yaitu Analisis Sosial Terhadap Sekolah Unggulan dan Non Unggulan Kabupaten Enrekang.

1. Masyarakat lebih melihat kebaikan sesuatu dari segi kualitas yang bisa dilihat mata secara langsung tanpa mempertimbangkan sekolah yang sedang berkembang, menganggap strategi sekolah unggulan lebih baik dari pada sekolah non unggulan, sekolah unggulan lebih disiplin dari pada sekolah non unggulan dan orang tua murid lebih memilih menyekolakan anaknya di sekolah unggulan dibandingkan sekolah non unggulan karena hasilnya dapat menjanjikan untuk masa depan anaknya

2. Kebijakan dari pihak pemerintah di mana mereka hanya bisa mengikuti aturan yang telah di perlakukan, Aturan pemerintah telah di tetapkan dan perlakukan sama rata terhadap sekolah tanpa memperhatikan status sekolah, seperti menerapakan standar pembelajaran, pembangunan sarana dan prasarana, standar tentang materi, standar biaya operasional dll dalam artian bahwa pemerintah tidak membedakan sekolah antara satu dengan sekolah yang lain. 


\section{DAFTAR PUSTAKA}

Alis Muhlis dan Norkholis, 2018 Analisis Tindakan Sosial Max Weber Dalam Tradisi Pembacaan Kitab Mukhtashar Al-Bukhari (Studi Living Hadis). Teknik Penentuan Informan

Upe,Ambo, 2010 : Tradisi Aliran Dalam Sosiologi , Positivisistik ke Post Positivistik : Kharisma Putra Utama Offset

Baharuddin, Pardigma Psikologi Islam, Yogyakarta: Pustaka Belajar, 2016,

Bogdan dan Biklen (dalam Syamsuddin dan Damaianti, 2011, hlm. 14) proses pelacakan dan pengaturan secara sistematis transkrip wawancara PT Rineka Cipta, 2015

Bungin,2016: 55-57 mengacaukan konsep-konsep lama tentang kontak sosial Yogyakarta: Pustaka Belajar, 2004

Calhoun dan Acocella (2017: 13) : interaksi individu sebab tanpa interaksi adaptasi tidak akan mungkin tercapai; Kumpulan-kumpulan pendapat para ahli tentang sosial : yokyakarta 2011

Gillin dan Gillin dalam Soekanto 2018: 71-104, dua golongan proses sosial sebagai akibat dan interaksi sosial, yaitu proses sosial asosiatif dan proses sosial disosiatif

Hubert Bonner (Santoso. 2017: 164) seperti yang dikutip oleh Dr. W. A. Gerungan, ia menjelaskan bahwa interaksi sosial mengubah atau memperbaiki kelakuan individu

Menurut Soekanto (2016: 54) interaksi sosial, sebab tanpa interaksi adaptasi tidak akan mungkin tercapai; Kumpulan-kumpulan pendapat para ahli tentang sosial : yogyakarta 2011

Mustofa Kamil, 2017:10 : lembaga khusus untuk pelatihan teknis dan profesional. Jakarta: PT Rineka Cipta, 2004

Skripsi : Rachmat Indryanto, 2018. Analisis Sosial Etnis Jawa Pada Masyarakat Di Kelurahan Sumpang Binangae Di Kecamatan Barru, Kabupaten Barru perpustakaan.upi.edu

Skripsi : Alis Muhlis dan Norkholis, 2013 Analisis Tindakan Sosial Max Weber Dalam Tradisi Pembacaan Kitab Mukhtashar Al-Bukhari (Studi Living Hadis). perpustakaan.upi.edu

Snowball sampling proses penentuan informan berdasarkan informan Jakarta: Darus Sunna Press, 2008

Sulherland (Huky BA \& Wila D.A.) interaksi sosial pengaruh-mempengaruhi secara dinamis antara kekuatan-kekuatan dalam mana kontak diantara pribadi dan kelompok menghasilkan perubahan sikap dan tingka laku dari pada partisipan : Surabaya: Usaha Nasional,

UUD Negara repobik Indonesia, Pasal 1 Undang-Undang Republik Indonesia No.20 Tahun 2016

Zuhairini, 1018 : 9 memiliki perana pokok dalam membentuk generasi muda agar memiliki kepribadian yang utama.: Bandung : Sinar Baru, 2002,) 